\title{
Efficiency analysis of standard and day 0 superovulatory protocols in Boer breed goats
}

\author{
Juraj Grizelj ${ }^{1}$, Branimira Špoljarić1, Tomislav Dobranić1, Martina Lojkić1, \\ Fernando Sánchez Dávila ${ }^{2}$, Marko Samardžija ${ }^{1}$, Foteini Samartzi ${ }^{3}$, \\ Iva Getz ${ }^{1}$, and Silvijo Vince ${ }^{1 *}$ \\ ${ }^{I}$ Clinic for Obstetrics and Reproduction, Faculty of Veterinary Medicine, University of Zagreb, \\ Zagreb, Croatia \\ ${ }^{2}$ Autonomous University of Nuevo Leon, Faculty of Agriculture, Laboratory of Animal Reproduction, Marin, \\ Nuevo Leon, Mexico \\ ${ }^{3}$ Veterinary Research Institute, Hellenic Agricultural Organization, Thermi-Thessaloniki, Greece
}

GRIZELJ, J., B. ŠPOLJARIĆ, T. DOBRANIĆ, M. LOJKIĆ, F. S. DÁVILA, M. SAMARDŽIJA, F. SAMARTZI, I. GETZ, S. VINCE: Efficiency analysis of standard and day 0 superovulatory protocols in Boer breed goats. Vet. arhiv 87, 473-486, 2017.

ABSTRACT

The aim of this research was to investigate the ovarian influence on the success of two superovulatory protocols in goats. Fifteen goats were used twice in the study in a crossover design: once within the control group where standard protocol was applied, and the other time in a modified, day 0 group, where no dominant follicle was present and the follicular cohort was homogenous ("Day 0 protocol"). All the animals were synchronized with vaginal pessaries and superovulated with 6 decreasing doses of $\mathrm{pFSH}$. Although the day 0 protocol significantly decreased the presence of the dominant follicle before the start of the superovulation treatment; it did not improve the superovulatory success. Fifty-four percent of goats in the control group had a dominant follicle which exerted a negative influence on the number of transferable embryos. The other $46 \%$ of goats from the same group had a very good superovulatory response, which improved the overall response of the control group in comparison with the day 0 group. Another reason for the lower superovulatory success of the day 0 protocol was the smaller number of second and third category follicles (3.5 - $5.5 \mathrm{~mm}$ in size) at the onset of the superovulation protocol, that positively correlated with the number of the transferable embryos $(\mathrm{r}=0.67 ; \mathrm{P}<0.05)$. In Boer goats, for the success of superovulatory treatment, the number of follicles of a certain size before the start of the superovulatory treatment has an effect as important as the effect of dominance. The application of the FSH hormone should start at the time when a suitable number of follicles belonging to the second category are present on the ovaries when performing the day 0 protocol.

Key words: goat, superovulation, dominant follicle, follicular population, embryo, superovulatory success

\footnotetext{
*Corresponding author:

Silvijo Vince, Clinic for Obstetrics and Reproduction, Faculty of Veterinary Medicine, University of Zagreb, Vjekoslava Heinzela 55, 10000 Zagreb, Croatia, Phone: +385 12390 185; E-mail: svince@,vef.hr
} 


\section{J. Grizelj et al.: Efficiency analysis of standard and day 0 superovulatory protocols in Boer breed goats}

\section{Introduction}

Goats are seasonal polyestric animals in mild climate regions, with the breeding season becoming longer towards the equator (ZARROUK et al., 2001). A year-round breeding season has also been observed in the Boer goat in mild continental climate regions (ĐURIČIĆ et al., 2009a), indicating that this kind of reproductive activity could be hereditary rather than environmentally influenced (DJURICIC et al., 2011). However, paragenetic factors such as dietary regime, should also be taken into account, particularly macroelements such as calcium and phosphorous serum levels (SAMARDŽIJA et al., 2011). Further, ĐURIČIĆ et al., (2012) reported that Boer goats, after they were introduced from the southern to the northern hemisphere, gradually became acclimated to a new seasonality. A higher percentage of live-born offspring were expected in Croatia during the optimal breeding season than in most European goat breeds (ĐURIĆIĆ et al., 2009a, 2009b).

Despite the progress achieved in goat breeding, commercial hormone preparations and protocols, the superovulatory response in goats is still characterized by high variability. The causes may be related to the sexual cycle phase and the influence of the ovary function (LINDSELL et al., 1986; WANI et al., 1992; ĐURIČIĆ et al., 2008). TASDEMIR et al. (2011) found that transferable embryo yield is affected by the breed while AYRES et al. (2012) found that superovulation can be reliably produced in goats, even without an exogenous source of progesterone.

The presence or absence of a dominant follicle is one of the factors that determines the success of the superovulatory response, as it affects the distribution of the follicular cohort and determines the ovulation percentage, as well as the number of embryos obtained (GONZALEZ-BULNES et al., 2000, 2003a, 2003b; MENCHACA et al., 2002; RUBIANES and MENCHACA, 2003; MENCHACA et al., 2007; GINTHER and KOT, 1994; DE CASTRO et al., 1999).

Concerning goats, there are records about the effect of the number of follicles ranging in size from 2-6 $\mathrm{mm}$ present at the start of the treatment on the percentage of ovulation, and those measuring 4-6 mm on the number of obtained embryos (GONZALEZ-BULNES et al., 2003a). Studies pertaining to ovarian factors show the significant effect of dominant follicles measuring $6 \mathrm{~mm}$ or more.

The aim of this research was to evaluate superovulatory response in Boer goats that were submitted to two different superovulatory protocols (standard and day 0 protocols) and to assess the role of ovarian factors - the follicular population and the presence of a dominant follicle at the start of superovulation treatment.

We hypothesize that the application of gonadotropin one day following ovulation could optimize superovulatory response in situations when there is no dominant follicle 
J. Grizelj et al.: Efficiency analysis of standard and day 0 superovulatory protocols in Boer breed goats

present but only a uniform follicular population starting to grow in the first wave (day 0 protocol).

\section{Materials and methods}

Fifteen Boer goats aged 1 to 3 years and $41.0 \pm 10.5 \mathrm{~kg}$ of live weight were included in the study, which was conducted during the breeding season (latitude $45^{\circ} \mathrm{N}$ ). The animals were fed with hay and concentrate twice a day and water was available ad libitum.

The animals were randomly divided into two groups: the control (standard protocol - C) and the day 0 group (experimental protocol - D0). Six to twelve weeks later, the protocol and the group were switched in a crossover design, so that every animal was submitted twice to superovulatory protocols. The superovulatory response was considered unsuccessful if early luteal regression or cysts were found, or if no ovulation occurred. Such animals were removed from further statistical analysis.

In order to analyse the influence of a dominant follicle, the results were additionally divided into two groups, depending on whether or not at the start of the superovulation a dominant follicle was present (dominant follicle - DF and, no dominant follicle - NO DF).

Day 0 group. The goats were submitted to oestrus synchronization using vaginal progestagen pessaries containing $40 \mathrm{mg}$ fluorogestone acetate (FGA) $\left(\right.$ Chronogest $^{\circledR}$, Intervet, Lima, Peru) during 11 days. Forty-eight hours before the pessaries were withdrawn, $250 \mathrm{IU}$ of equine chorionic gonadotropin (eCG) (Folligon ${ }^{\circledR}$, Intervet, Boxmeer, The Netherlands) and $50 \mu \mathrm{g}$ of cloprostenol (Estrumate ${ }^{\circledR}$, Schering-Plough, Friesoythe, Germany) were applied intramuscularly (i/m).

Twenty-four hours after pessary withdrawal, the detection of oestrus was performed every 4 hours until positive detection occurred. Induction of ovulation was done 12 hours following positive oestrus detection by $\mathrm{i} / \mathrm{m}$ application of $8.4 \mu \mathrm{g}$ of a gonadotropin releasing hormone $(\mathrm{GnRH})$ analogue, buserelin acetat $\left(\right.$ Receptal $^{\circledR}$, Intervet, Boxmeer, The Netherlands).

Forty-eight hours after GnRH analogue application, a superovulation protocol that consisted of $6 \mathrm{i} / \mathrm{m}$ doses of porcine follicle-stimulating hormone (pFSH) (Folltropin ${ }^{\circledR}$, Vetrepharm, Belleville, Canada), injected every 12 hours (50 mg $+50 \mathrm{mg}, 25 \mathrm{mg}+25$ $\mathrm{mg}, 25 \mathrm{mg}+25 \mathrm{mg}$ ) was applied. After the fifth and sixth pFSH injection, cloprostenol, at a dose of $50 \mu \mathrm{g}$ was applied. The following day - i.e. 24 hours after, oestrus detection was performed every 4 hours using an adult buck wearing an apron. If oestrus was detected, the goat was mated individually twice a day at an 8-10 hour interval, and the following day if oestrus was still detectable. The time frame was recorded in which oestrus was detected following the fifth dose of $\mathrm{pFSH}$ and cloprostenol injection, as well as the duration of oestrus. 


\section{J. Grizelj et al.: Efficiency analysis of standard and day 0 superovulatory protocols in Boer breed goats}

Control group. Progestagen pessaries were inserted and left for 11 days. A single injection of $50 \mu \mathrm{g}$ of cloprostenol was applied on day 9 following the insertion of the pessaries, in the morning, simultaneously with the superovulatory treatment, which was the same as described previously. Oestrus detection and mating were performed as described previously. The time frame in which oestrus appeared following the pessary removal was recorded for each animal, together with the duration of oestrus.

\section{Treatments designed for all goats included in the study}

Laparotomy for uterine flushing and the anaesthetic protocol. The ovulations were confirmed during ultrasound examinations the day before uterine flushing by detection and counting of CLs. Uterine flushing was performed by laparotomy, 7 days after the first mating (D7). Anaesthesia was induced with $0.11 \mathrm{mg} / \mathrm{kg}$ of xylazine (Xylapan ${ }^{\circledR}$, Vetoquinol) $\mathrm{i} / \mathrm{m}$ followed by an $\mathrm{i} / \mathrm{m}$ injection of $5.5 \mathrm{mg} / \mathrm{kg}$ of ketamine (Narketan ${ }^{\circledR}$, Vetoquinol) $10 \mathrm{~min}$ later.

The does were placed in a dorsal recumbent position on an inclined surgical table, with their head on the lower end. The uterus and ovaries were exteriorised by medioventral laparotomy, the number of CLs recorded, and punction was performed at the base and the tip of each uterine horn. The flushing was performed by retrograde perfusion of $40 \mathrm{~mL}$ of Phosphate-Buffered Saline (PBS) + 2g/L Bovine Serum Albumin (BSA) + 50mg/L Kanamycin (Sigma-K1377, Sigma-Aldrich). The flushing medium was analysed and obtained embryos evaluated according to the criteria of International Embryo Transfer Society - IETS. The following structures were evaluated and counted: total number of collected forms, number of transferable and non-transferable embryos, and number of non-developed / retarded embryos. The rate of flushing success was calculated, as well as the percentage of fertilized oocytes, and vital and retarded embryos.

Ultrasound exams. The ovarian status of each animal was monitored by ultrasound examinations performed before and during superovulatory treatment, until ovulation occurred. The goats were placed in dorsal recumbent position and a $7.5 \mathrm{MHz}$ lubricated linear array ultrasound probe was placed into the rectum (Sonovet 2000, Medison Co.). A concave rod was used to reinforce the probe, as it was attached to an insufficiently firm cable (GRIZELJ et al., 2013). The lubricant containing local anaesthetic was applied in a rectal ampulla 5 min before introducing the rectal probe (Lidocaine $2 \%$ diluted in ultrasound gel in ratio 1:10). The scanning of ovaries was done once a day before the start and during the superovulation protocol in order to count and measure the follicles $\geq 2 \mathrm{~mm}$.

Statistical analysis. The animals that did not respond to superovulatory treatment $(<5 \mathrm{CLs})$ were omitted from the statistical analysis concerning the results obtained after flushing the uterus. Statistical analysis was performed using the procedure program package SAS 9.1.3. Service Pack 4 (2002-2003 by SAS Institute Inc.). The probability of differences in superovulatory success between the analysed groups, and the difference 
J. Grizelj et al.: Efficiency analysis of standard and day 0 superovulatory protocols in Boer breed goats

in the follicular dynamics was calculated using the SAS module PROC GLM when the fixed effects and PROC MIXED when random and fixed effects were analysed in the model. Pearson's correlation coefficient (PROC CORR) was used to identify the correlation coefficient of the number of CLs with the number of collected forms and the number of specific categories' follicles before the first FSH injection, with the number of collected forms and the number of transferable embryos. When the presumption of normal distribution of the analysed dependent variables and heterogeneity of variances was disturbed, the analysis was done using PROC GENMOD, or transformation of the dependent variable was used. The statistical significance was set at $\mathrm{P}<0.05$. Figures were made using the PROC GCHART module of SAS.

\section{Results}

Superovulatory response in goats. Of the 30 goats in which superovulatory treatment was used a good response was obtained, which means at least 5 ovulations, in 25 animals (83.3\%). One of them did not exhibit any behavioural signs of oestrus and hence was not mated. Three goats had an early luteal regression, and one did not ovulate at all.

Uterine flushing efficiency rate. A total of 219 ova/embryo forms were found in the flushed media, $311 \mathrm{CLs}$ were counted on ovaries, and the average flushing efficiency rate (number of CL / number of collected cellular forms) was $73.2 \%(\mathrm{r}=0.80 ; \mathrm{P}<0.0001)$. The efficiency rate of the first and the second flushing was $74.1 \%$ and $71.8 \%$, respectively.

Table 1. Distribution of evaluated collected forms (percentage of fertilized oocytes, degenerated and transferable embryos

\begin{tabular}{|c|c|c|c|c|}
\hline $\begin{array}{c}\text { No. of collected } \\
\text { forms (oocytes } \\
\text { and embryos) }\end{array}$ & $\begin{array}{c}\text { No. of fertilized/ } \\
\text { collected forms }\end{array}$ & $\begin{array}{c}\text { Degenerated } \\
\text { embryos / } \\
\text { collected forms }\end{array}$ & $\begin{array}{c}\text { Transferable } \\
\text { embryos / } \\
\text { collected forms }\end{array}$ & $\begin{array}{c}\text { Grade 1 and 2 / } \\
\text { total embryos }\end{array}$ \\
\hline 219 & $\begin{array}{c}81.7 \% \\
(179 / 219)\end{array}$ & $\begin{array}{c}14.6 \% \\
(32 / 219)\end{array}$ & $\begin{array}{c}61.1 \% \\
(134 / 219)\end{array}$ & $\begin{array}{c}74.9 \% \\
(134 / 179)\end{array}$ \\
\hline
\end{tabular}

At the start of the superovulatory treatment, 8 out of 25 goats had a dominant follicle present on their ovaries (size $\geq 6 \mathrm{~mm}$ ); 7 of 13 from the control group (54\%) and 1 of 12 from the day 0 group ( $8 \%$ ). The follicular status at the beginning of the superovulatory treatment and superovulatory response for different protocols and animals with or without dominant follicle are shown in Table 2.

The average number of follicles within different follicular categories are shown in Figs 1 and 2, from the first FSH injection until ovulation occurred. The positive and statistically significant correlations between the number of second category follicles with the number of collected cellular forms and the number of transferable embryos were found $(r=0.62$ and $r=0.67 ; P<0.05)$, respectively. 


\section{J. Grizelj et al.: Efficiency analysis of standard and day 0 superovulatory protocols in Boer breed goats}

Table 2. Ovarian follicular status at the start of superovulation treatment and superovulation response. The control group was compared with the day 0 group, and the animals with a dominant follicle (DF) at time of the first FSH dose were compared with the animals without a dominant follicle (NO_DF).

\begin{tabular}{|l|c|c|c|c|c|c|}
\hline & $\begin{array}{c}\text { Control } \\
\text { group }\end{array}$ & $\begin{array}{c}\text { Day 0 } \\
\text { group }\end{array}$ & P value & DF & No DF & P value \\
\hline $\begin{array}{l}\text { Average size of the biggest } \\
\text { follicle at the start of the } \\
\text { protocol (mm) }\end{array}$ & $\begin{array}{c}5.46 \\
\pm 0.40\end{array}$ & $\begin{array}{c}3.12 \\
\pm 0.40\end{array}$ & $<0.001$ & $\begin{array}{c}6.50 \\
\pm 0.31\end{array}$ & $\begin{array}{c}3.32 \\
\pm 0.26\end{array}$ & $<0.001$ \\
\hline $\begin{array}{l}\text { Average size of all follicles } \\
\text { present at the start of the } \\
\text { protocol (mm) }\end{array}$ & $\begin{array}{c}3.14 \\
\pm 0.12\end{array}$ & $\begin{array}{c}2.50 \\
\pm 0.07\end{array}$ & $<0.001$ & $\begin{array}{c}3.20 \\
\pm 0.20\end{array}$ & $\begin{array}{c}2.66 \\
\pm 0.07\end{array}$ & $<0.07$ \\
\hline $\begin{array}{l}\text { Average size (mm) of all } \\
\text { follicles at the start of the } \\
\text { protocol, excluding the } \\
\text { dominant follicles ( } \geq 6 \text { mm) }\end{array}$ & $\begin{array}{c}2.88 \\
\pm 0.09\end{array}$ & $\begin{array}{c}2.46 \\
\pm 0.07\end{array}$ & $<0.01$ & $\begin{array}{c}2.70 \\
\pm 0.11\end{array}$ & $\begin{array}{c}2.66 \\
\pm 0.07\end{array}$ & n.s. \\
\hline $\begin{array}{l}\text { Average size of all follicles 24 h } \\
\text { after GnRH application (mm) }\end{array}$ & $-\begin{array}{c}2.31 \\
\pm 0.12\end{array}$ & - & - & - & - \\
\hline Average number of CL & $\begin{array}{l}17.75 \\
\pm 1.88\end{array}$ & $\begin{array}{c}10.89 \\
\pm 1.76\end{array}$ & $<0.05$ & $\begin{array}{c}12.63 \\
\pm 2.73\end{array}$ & $\begin{array}{c}13.40 \\
\pm 2.30\end{array}$ & n.s. \\
\hline $\begin{array}{l}\text { Average number of collected } \\
\text { forms }\end{array}$ & $\begin{array}{l}12.67 \\
\pm 1.71\end{array}$ & $\begin{array}{c}7.44 \\
\pm 0.95\end{array}$ & $<0.05$ & $\begin{array}{c}10.30 \\
\pm 1.81\end{array}$ & $\begin{array}{c}10.70 \\
\pm 1.54\end{array}$ & n.s. \\
\hline $\begin{array}{l}\text { Average number of transferable } \\
\text { embryos }\end{array}$ & $\begin{array}{c}7.25 \\
\pm 1.51\end{array}$ & $\begin{array}{c}5.22 \\
\pm 1.17\end{array}$ & $<0.05$ & $\begin{array}{c}3.85 \\
\pm 1.01\end{array}$ & $\begin{array}{c}7.64 \\
\pm 1.31\end{array}$ & $<0.05$ \\
\hline $\begin{array}{l}\text { Average number of non- } \\
\text { transferable embryos }\end{array}$ & $\begin{array}{c}5.00 \\
\pm 1.08\end{array}$ & $\begin{array}{c}2.20 \\
\pm 1.00\end{array}$ & n.s. & $\begin{array}{c}6.10 \\
\pm 1.60\end{array}$ & $\begin{array}{c}2.59 \\
\pm 1.25\end{array}$ & 0.05 \\
\hline $\begin{array}{l}\text { Average number of first grade } \\
\text { embryos }\end{array}$ & $\begin{array}{c}5.92 \\
\pm 1.58\end{array}$ & $\begin{array}{c}5.00 \\
\pm 1.31\end{array}$ & n.s. & $\begin{array}{c}2.85 \\
\pm 0.98\end{array}$ & $\begin{array}{c}7.00 \\
\pm 1.19\end{array}$ & $<0.05$ \\
\hline $\begin{array}{l}\text { Transferable embryos/total } \\
\text { number of collected forms }(\%)\end{array}$ & $\begin{array}{l}56.30 \\
\pm 7.63\end{array}$ & $\begin{array}{c}69.87 \\
\pm 8.63\end{array}$ & n.s. & $\begin{array}{c}40.84 \\
\pm 11.16\end{array}$ & $\begin{array}{l}69.62 \\
\pm 6.47\end{array}$ & $<0.05$ \\
\hline
\end{tabular}

n.s. - not statistically significant 
J. Grizelj et al.: Efficiency analysis of standard and day 0 superovulatory protocols in Boer breed goats

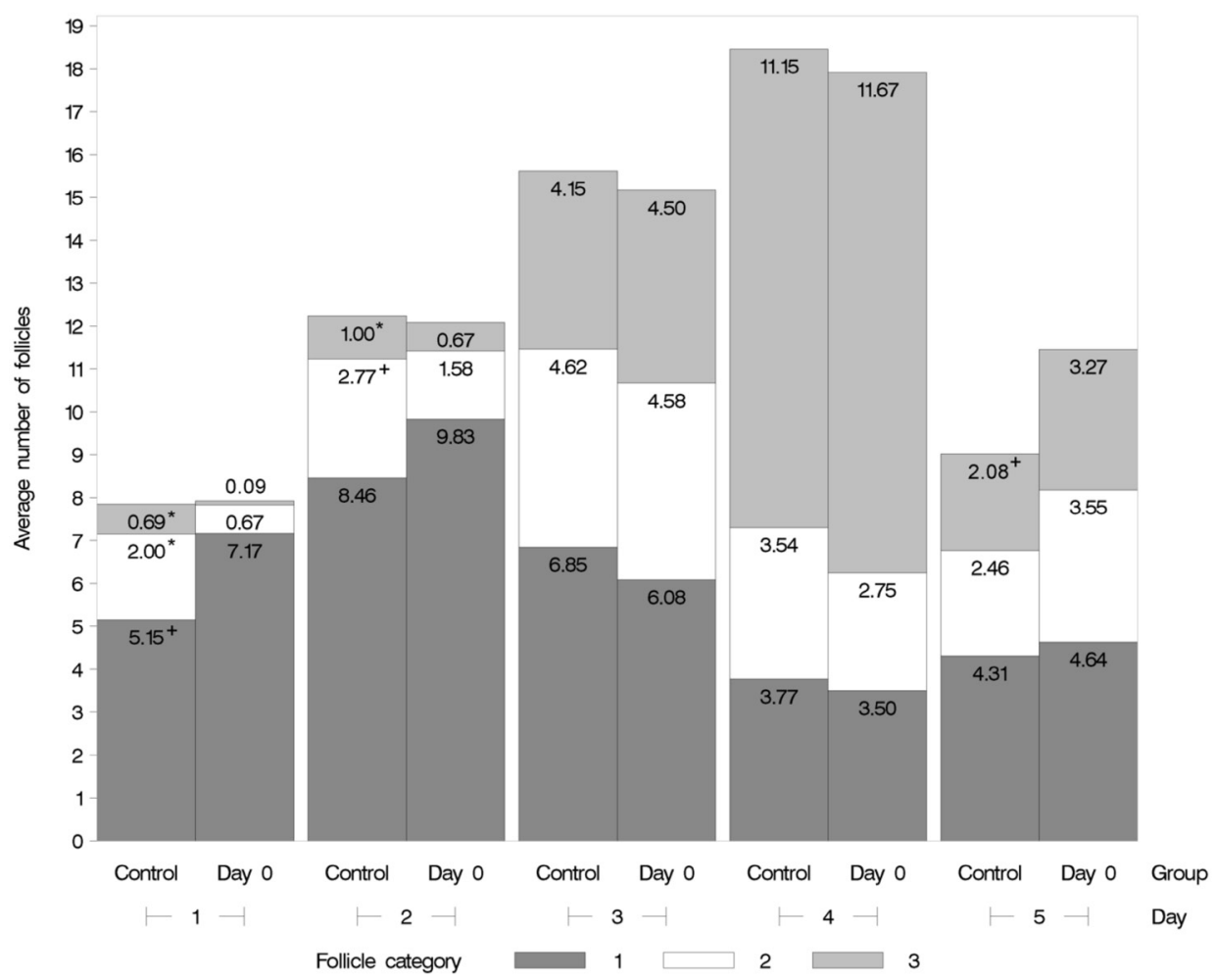

Fig. 1. Histogram showing a comparison of the average number of follicles within three follicular categories during the superovulation treatment between the control and the day 0 groups.

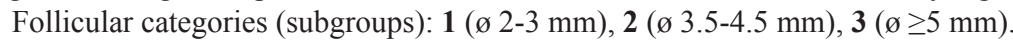

Day 1 ( $0 \mathrm{~h}$, before the first FSH injection), $\mathbf{2}$ (before the third FSH injection; $24 \mathrm{~h}$ ), 3 (before the fifth FSH injection; $48 \mathrm{~h}$ ), 4 (at the start of estrus; 72-78 h), 5 (after the ovulation, 112-120 h).

* Statistically significant difference in the number of follicles within the same follicle category between the control (C) and day 0 (D0) groups $(\mathrm{P}<0.05)$.

${ }^{+}$Values that were close to statistically significant difference $(\mathrm{P}<0.10)$ in the number of follicles within the same follicle category between the control (C) and day 0 (D0) groups. 
J. Grizelj et al.: Efficiency analysis of standard and day 0 superovulatory protocols in Boer breed goats

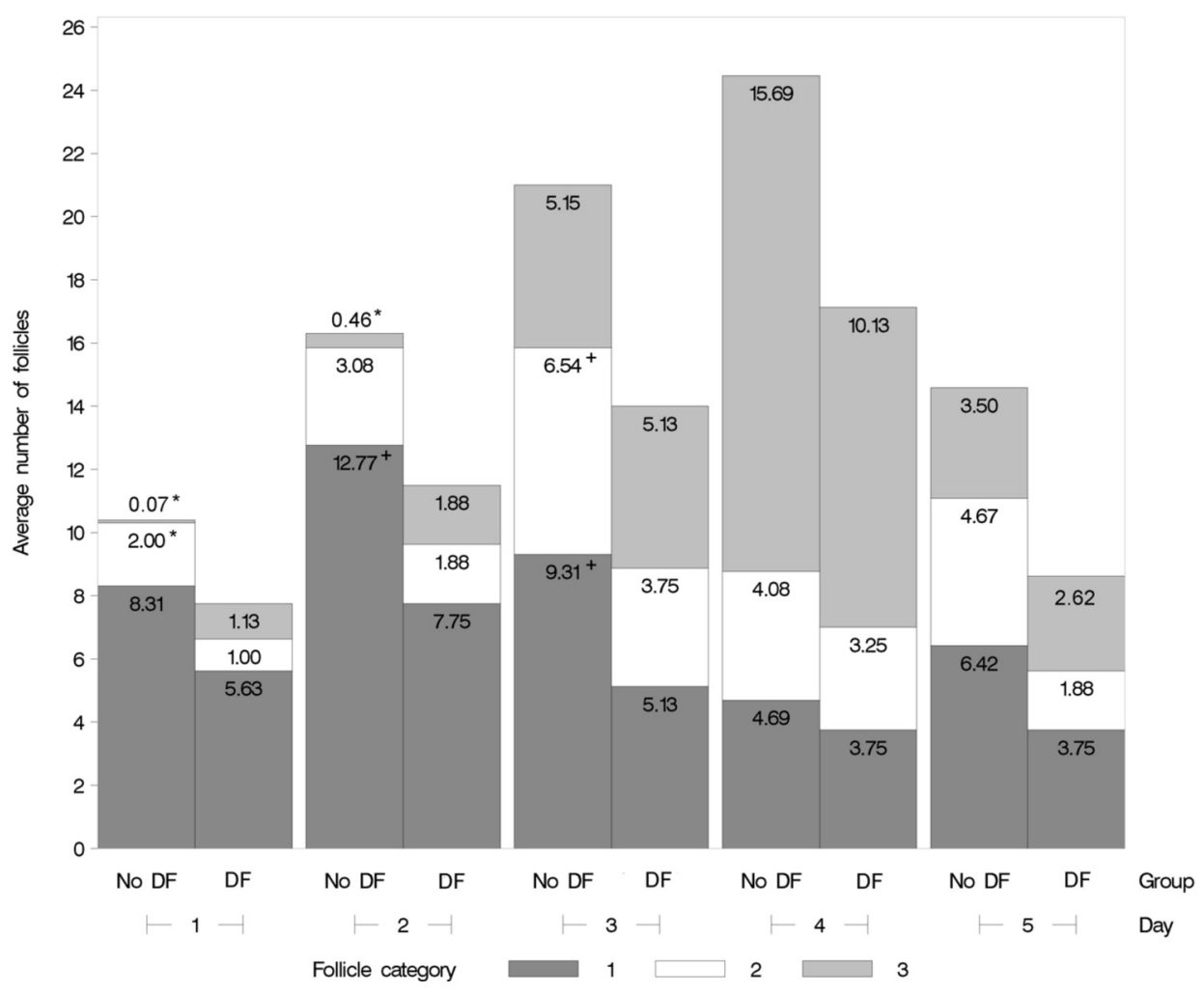

Fig. 2. Histogram showing comparison of the average number of follicles within three follicular categories during the superovulation treatment between animals with a dominant follicle present

(DF) and those without a dominant follicle (NO_DF) at the time of the first FSH injection.

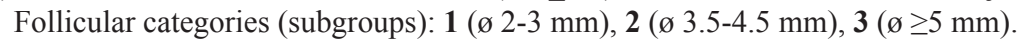

Day 1 ( $0 \mathrm{~h}$, before the first FSH injection), 2 (before the third FSH injection; $24 \mathrm{~h}$ ), 3 (before the fifth FSH injection; $48 \mathrm{~h}$ ), 4 (the start of oestrus; 72-78 h), 5 (after ovulation, 112-120 h).

* A statistically significant difference in the number of follicles within the same follicle category between the group with a dominant follicle present (DF) and the group without a dominant follicle (NO_DF) $(\mathrm{P}<0.05)$.

${ }^{+}$Values that were close to statistically significant difference $(\mathrm{P}<0.10)$ in the number of follicles within the same follicle category between the group with a dominant follicle present (DF) and group without a dominant follicle (NO_DF). 
J. Grizelj et al.: Efficiency analysis of standard and day 0 superovulatory protocols in Boer breed goats

\section{Discussion}

The flushing success rate in this study is very close to the result obtained by SENLIS (1990) who had a laparotomic uterine flushing efficiency rate of $71 \%$. In the current study, the success of the first flushing was slightly higher than the second one, with no statistically significant difference $(\mathrm{P}<0.10)$.

In the current study, the average number of CLs counted on the ovaries of all animals in both groups was $14.8 \pm 1.5$, which was consistent with previous research done by GONZALEZ-BULNES et al. (2003a), SENTHIL-KUMAR et al. (2003) and GREYLING et al. (2002), respectively. This number is one of the vital parameters used to evaluate the success of the superovulation treatment, and it depends on several factors, such as the source of gonadotropins, differences in protocol applied, the breed of the animals and the season in which the research was conducted (GARZA et al., 2015).

In this study a statistically significant difference was found in the total number of CLs between the control and day 0 groups of animals. The day 0 group had a significantly lower number of CLs, and this finding corresponds to the results obtained by a similar protocol in the study conducted by MENCHACA et al. (2007) and LEHLOENYA and GREYLING (2010).

The average number of collected forms for all the animals included in this study was slightly higher when compared with research done in other breeds of goats (PENDLETON et al., 1992; SELVARAJU et al., 2003; SENTHIL-KUMAR et al., 2003). This may indicate that Boer goats respond better to superovulatory treatment.

The average number of transferable embryos for all goats in this research was 6.38 \pm 1.0 , and the percentage of transferable embryos within the collected forms (embryo viability) was $60.03 \pm 6.3 \%$, which is consistent with the results obtained by SENTHILKUMAR et al. (2003) and GONZALEZ-BULNES et al. (2003a).

The average number of non-transferable embryos in this research was almost five times higher than that in results obtained by SENTHIL-KUMAR et al. (2003). The same occurred with the number of non-fertilized oocytes, while the percentage of fertilization was similar to the results of other researchers (KHOBOSO, 2008; MENCHACA et al., 2007). Interestingly, the number of non-fertilized oocytes in the current study was two times lower than that obtained by KHOBOSO (2008).

When compared to the experimental group (day 0), the control group in the current study had a significantly higher number of collected forms and a higher number of transferable embryos which was close to statistically significant difference $(\mathrm{P} \leq 0.10)$. On the other hand, concerning the number of collected forms and transferable embryos MENCHACA et al. (2007) in their research reported similar results obtained from the experimental group; however, their control group had a significantly smaller number of 
collected forms and transferable embryos when compared to the results obtained from the control group in this study. The most likely reason for this discrepancy is that at the beginning of superovulation treatment a dominant follicle (measuring $\geq 6 \mathrm{~mm}$ ) was observed in $85 \%$ of animals.

Moreover, animals with a dominant follicle at the beginning of the treatment showed asynchronous growth of the follicles during superovulation, and most of those did not ovulate, what probably caused the small number of transferable embryos obtained. However, it seems that the dominant follicle did not hamper the development of the other follicles during the treatment with FSH.

In the current study, there was no association between the number of follicles of each category, the time when the superovulation protocol started and the number of obtained transferable embryos. This fact suggests that, although the application of exogenous FSH may induce the development of the follicles to pre-ovulatory size, following ovulation and fertilization not all the oocytes have the capacity to become vital (transferable) embryos. Since there was no difference in the number of CLs and the number of collected forms between the animals with and those without a dominant follicle, we hypothesize that the most probable reason for the lower ovulation rate in the day 0 group could be a particular follicular population that was present at the beginning of the superovulation treatment. This is further supported by the results of similar studies in which the presence of a dominant follicle measuring $\geq 6 \mathrm{~mm}$ at the beginning of superovulatory treatment with multiple doses of FSH did not significantly influence the percentage of ovulation (GONZALEZ-BULNES et al., 2000, 2003a, 2003b).

Similar positive correlations between the number of follicles measuring 2 to $6 \mathrm{~mm}$ and the number of CLs, as well as the number of follicles measuring 4 to $6 \mathrm{~mm}$ and the number of transferable embryos, were found by GONZALEZ-BULNES et al. (2003a). According to DE SMEDT et al. (1994) oocytes are capable of reaching maturity only within follicles measuring more than $3 \mathrm{~mm}$ in diameter. Oocytes that come from smaller follicles are either hard to fertilize or develop following fertilization into retarded or non-transferable embryos. Likewise, in our study, the group of goats without a dominant follicle had a significantly higher percentage of transferable embryos, and particularly a higher number of first class embryos. On the other hand, the group of goats with a dominant follicle had a greater number of non-transferable embryos, and the difference was close to statistically significant $(\mathrm{P}=0.07)$. The average diameter of the follicles in the day 0 group on the first day of the experiment was significantly lower than in the control group. Such a low average follicular diameter on the first day of the experiment could be the result of the particularities of the applied protocol, i.e. the fixed time when the superovulation protocolsbegan. The day 0 protocol began $24 \mathrm{~h}$ following induced ovulation, i.e. $48 \mathrm{~h}$ after GnRH application. For the majority of goats, twenty-four hours 
after induced ovulation was obviously an insufficient length of time for development of follicles larger than $3 \mathrm{~mm}$ in diameter. The slower follicular growth after ovulation could indicate that Boer goats may be prone to have a smaller number of follicular waves during the sexual cycle, while most authors indicate four follicular waves as an average in the sexual cycle of goats (GINTHER and KOT, 1994; DE CASTRO et al., 1999; SCHWARZ and WIERZCHOS, 2000; MENCHACA and RUBIANES, 2002). Another reason for the slower follicular growth could be application of the $\mathrm{GnRH}$ analogue, given $48 \mathrm{~h}$ before the start of the superovulation treatment in order to synchronize ovulation. Likewise, less successful flushing and a smaller number of transferable embryos obtained were recorded in a study where a GnRH analogue was given as part of the superovulation protocol (KHOBOSO, 2008). The author suggests that the reason for the failure of the superovulation treatment could be the low levels of LH hormone that impeded maturation of the oocytes. These results are contradictory to a previous research where a higher number of transferable embryos were obtained (COGNIE et al., 2003).

\section{Conclusions}

The modified day 0 protocol significantly reduced the number of animals with a dominant follicle present before the start of superovulation. It also reduced the number of follicles measuring 3 to $5.5 \mathrm{~mm}$. Goats that had a dominant follicle present at the time when the superovulation procedure started had fewer second category follicles at the time when the first FSH dose was injected, and fewer transferable embryos.

The animals with dominant follicles had uneven follicular growth due to atresia and disturbed follicular recruitment, and they had a large number of non-transferable embryos. In Boer goats, the number of follicles of a certain size before the start of the superovulation treatment has an effect as important as the effect of dominance.

The application of FSH hormone when performing the modified (day 0) protocol should start at the time when a suitable number of follicles belonging to the second category are present on the ovaries.

\section{Acknowledgements}

This research was partially supported by the Agence Universitaire de la Francophonie project (AUF) 'L'optimisation des paramètres de reproduction, de génétique et de santé pour l'amélioration de la production des troupeaux de chèvres“.

\section{Reference}

AYRES, S. L., W. GAVIN, E. MEMILI, E. BEHBOODI (2012): Superovulation in goats during the second follicular wave, with or without exogenous progesterone. Small Rumin. Res. 104, $146-150$. 
J. Grizelj et al.: Efficiency analysis of standard and day 0 superovulatory protocols in Boer breed goats

COGNIE, Y., G., BARIL, N. POULIN, P. MERMILLOD (2003): Current status of embryo technologies in sheep and goat. Theriogenology 59, 171-188.

DE CASTRO, T., E. RUBIANES, A. MENCHACA, A. RIVERO (1999): Ovarian dynamics, serum estradiol and progesterone concentrations during the interovulatory interval in goats. Theriogenology 52, 399-411.

DE SMEDT, V., N. CROZET, L. GALL (1994): Morphological and functional changes accompanying the acquisition of meiotic competence in ovarian goat oocyte. J. Exp. Zool. 269, 128-139.

DJURICIC, D., T. DOBRANIC, J. GRIZELJ, D. GRACNER, I. HARAPIN, D. STANIN, I. FOLNOZIC, I. GETZ, D. CVITKOVIC, M. SAMARDZIJA (2011): Concentrations of total proteins and albumins, and AST, AP, CK and GGT activities in the blood sera Boer and Saanen goats during puerperium. Reprod. Domest. Anim. 46, 674-677.

ĐURIČIĆ, D., T. DOBRANIĆ, M. SAMARDŽIJA, I. HARAPIN, S. VINCE, J. GRIZELJ, N. PRVANOVIĆ, D. GRAČNER, LJ. BEDRICA, D. CVITKOVIĆ (2008): Analyse der Ovarienaktivität der Burenziegen im Puerperium locksmithing des Stoffwechsel- und Hormonprofils. Tierärztl. Umschau 63, 370-376.

ĐURIČIĆ, D., M. SAMARDŽIJA, T. DOBRANIĆ, L. VUKOŠA, I. HARAPIN, D. GRAČNER, Ž. PAVIČIĆ (2009a): Einfluss der Jahreszeit auf die Serviceperiode und Zwischenlammzeit bei Burenziegen im nordwestlichen Teil Kroatiens. Tierärztl. Umschau 64, 24-29.

ĐURIČIĆ, D., T. DOBRANIĆ, M. SAMARDŽIJA, S. VINCE, J. GRIZELJ (2009b): Fruchtbarkeitsmerkmale der Burenziegen im nordwestlichen Teil Kroatiens. Tierärztl. Umschau 64, 384-388.

ĐURIČIĆ, D., J. GRIZELJ, T. DOBRANIĆ, I. HARAPIN, S. VINCE, P. KOČILA, I. FOLNOŽIĆ, M. LIPAR, G. GREGURIĆ GRAČNER, M. SAMARDŽIJA(2012): Reproductive performance of boer goats in a moderate climate zone. Vet. arhiv 82, 351-358.

GARZA, A., A. GOMEZ, F. VASQUEZ ARMIJO, R. A. LEDEZMA-TORRES, H. BERNAL, F. SANCHEZ DAVILA (2015): Status and implementation of reproductive technologies in goats in emerging countries. Review. Afr. J. Biotechnol. 14, 719-727.

GINTHER, O. J., K. KOT (1994): Follicular dynamics during the ovulatory season in goats. Theriogenology 42, 987-1001.

GONZALEZ-BUlneS, A., J. SANTIAGO-MORENO, M. J. COCERO, A. LOPEZSEBASTIAN (2000): Effects of FSH commercial preparation and follicular status on follicular growth and superovulatory response in Spanish Merino ewes. Theriogenology 54, 1055-1064.

GONZALEZ-BULNES, A., J. A. CARRIZOSA, C. DIAZ-DELFA, R. M. GARCIA-GARCIA, B. URRUTIA, J. SANTIAGO-MORENO, M. J. COCERO, A. LOPEZ-SEBASTIAN (2003a): Effects of ovarian follicular status on superovulatory response of dairy goats to FSH treatment. Small Rumin. Res. 48, 9-14.

GONZALEZ-BULNES, A., R. M. GARCIA-GARCIA, J. SANTIAGO-MORENO, V. DOMINGUEZ, A. LOPEZ-SEBASTIAN, M. J. COCERO (2003b): Reproductive season 
J. Grizelj et al.: Efficiency analysis of standard and day 0 superovulatory protocols in Boer breed goats

affects inhibitory effects from large follicles on the response to superovulatory FSH treatments in ewes. Theriogenology 60, 281-288.

GREYLING, J. P. C., M. VAN DER NEST, L. M. J. SCHWALBACH, T. MULLER, (2002): Superovulation and embryo transfer in South African boer and indigenous feral goats. Small Rumin. Res. 43, 45-51.

GRIZELJ, J., S. VINCE, M. SAMARDŽIJA, A. GONZALEZ-BULNES, T. DOVENSKI, L. TURMALAJ, B. ŽEVRNJA (2013): Use of ultrasonography to detect ovarian response in goats submitted to multiple ovulation and embryo transfer program. Vet. arhiv 83, 125-134.

IETS (1998): In: Manual of the International Embryo Transfer Society, $3^{\text {rd }}$ edition. (Stringfellow, D. A., S. M. Seidel, Eds.). IL, USA, Savoy. 106-107.

KHOBOSO, C. L. (2008): Multiple ovulation and embryo transfer in goats. PhD Thesis. Faculty of Natural and Agricultural Sciences, Department of Animal, Wildlife and Grassland Sciences University of the Free State Bloemfontein.

LEHLOENYA, K. C., J. P. C. GREYLING (2010): The ovarian response and embryo recovery rate in Boer goat does following different superovulation protocols, during the breeding season. Small Rumin. Res. 88, 38-43.

LINDSELL, C. W., B. D. MURPHY, R. J. MAPLETOFT (1986): Superovulatory and endocrine responses in heifers treated with FSH-P at different stages of estrus cycle. Theriogenology 26, 209-219.

MENCHACA, A., A. PINCZAK, E. RUBIANES (2002): Follicular recruitment and ovulatory response to FSH treatment initiated on day 0 or day 3 post-ovulation in goats. Theriogenology $58,1713-1721$.

MENCHACA, A., E. RUBIANES (2002): Relation between progesterone concentrations during the early luteal phase and follicular dynamic in goats. Theriogenology 57, 1411-1419.

MENCHACA, A., M. VILARIÑO, M. CRISPO, A. PINCZAK, E. RUBIANES (2007): Day 0 Protocol: Superstimulatory treatment initiated in the absence of a large follicle improves ovarian response and embryo yield in goats. Theriogenology 68, 1111-1117.

PENDleton, R. J., C. R. YOUNGS, R. W. RORIE, S. H. POOL, M. A. MEMON, R. A. GODKE (1992): Follicle stimulating hormone versus pregnant mare serum gonadotropin for superovulation of dairy goats. Small Rumin. Res. 8, 217-224.

RUBIANES, E., A. MENCHACA (2003): The pattern and manipulation of ovarian follicular growth in goats. Anim. Reprod. Sci. 78, 271-287.

SAMARDŽIJA, M., T. DOBRANIĆ, M. LIPAR, I. HARAPIN, N. PRVANOVIĆ, J. GRIZELJ, G. GREGURIĆ-GRAČNER, V. DOBRANIĆ, B. RADIŠIĆ, D. ĐURIČIĆ (2011): Comparison of blood serum macrominerals concentrations in meat and dairy goats during puerperium. Vet. arhiv 81, 1-11.

SAS INSTITUTE INC. URL: http://support.sas.com /onlinedoc/913/docMainpage.jsp [04. 02. 2015].

SCHWARZ, T., E. WIERZCHOS (2000): Relationship between FSH and ovarian follicular dynamics in goats during the estrus cycle. Theriogenology 53, 381. 
J. Grizelj et al.: Efficiency analysis of standard and day 0 superovulatory protocols in Boer breed goats

SElVARAJU, S., S. K. AGARWAL, S. D. KARCHE, A. C. MAJUMDAR (2003): Ovarian response, embryo production and hormonal profile in superovulated goats treated with insulin. Theriogenology 59, 1459-1468.

SENLIS, Y. (1990): Fécondation in vitro chez les caprins: effet de la race et de la saison. Mémoire de fin d'Etudes, ENSAIA Nancy, France, 35.

SENTHIL-KUMAR, P., D. SARAVANAN, R. C. RAJASUNDARAM, M. SELVARAJU, D. KATHIRESAN (2003): Serum oestradiol and progesterone profiles and their relationship with superovulatory responses in Tellicherry goats treated with eCG and FSH. Small Rumin. Res. 49, 69-77.

TASDEMIR, U., A. R. AGAOGLU, M. KAYMAZ, K. KARAKAS (2011): Ovarian response and embryo yield of Angora and Kilis goats given the day 0 protocol for superovulation in the nonbreeding season. Trop. Anim. Health Pro. 43, 1035-1038.

WANI, G. M., H. GELDERMANN, J. HAHN (1992): Superovulations during early luteal phase in goats' world. Rev. Anim. Prod. 25, 41-43.

ZARROUK, A., O. SOUILEM, P. V. DRION, J. F. BECKERS (2001): Caracteristiques de la reproduction de l'espece caprine. Ann. Med. Vet. 145, 98-105.

Received: 15 March 2016

Accepted: 7 October 2016

\section{GRIZELJ, J., B. ŠPOLJARIĆ, T. DOBRANIĆ, M. LOJKIĆ, F. S. DÁVILA, M. SAMARDŽIJA, F. SAMARTZI, I. GETZ, S. VINCE: Analiza učinkovitosti standardnoga protokola i nulti dan superovulacijskog protokola u koza burske pasmine. Vet. arhiv 87, 473-486, 2017.}

\section{SAŽETAK}

Cilj ovog istraživanja bio je istražiti utjecaj jajnika na uspjeh dvaju superovulacijskih protokola u koza. Petnaest je koza u istraživanju korišteno dva puta u ukriženom dizajnu; prvi puta u kontrolnoj skupini standardnoga protokola, a nakon toga u modificiranom „dan 0" protokolu gdje nije bilo prisutnog dominantnog folikula, a folikularna kohorta je homogena. Sve životinje sinkronizirane su vaginalnim spužvicama te superovulirane sa 6 primjena padajućih doza pFSH. Iako je „dan 0” protokol znakovito smanjio prisutnost dominantnog folikula prije početka superovulacijskog postupka, protokol nije poboljšao uspjeh superovulacije. Pedeset i četiri posto koza u kontrolnoj skupini imalo je dominantan folikul koji je ispoljio negativan učinak na broj transferabilnih zametaka. Ostalih $46 \%$ koza iz iste skupine imalo je vrlo dobar superovulacijski odgovor što je popravilo ukupni odgovor kontrolne skupine u odnosu na „dan 0" skupinu. Drugi razlog za slabiji uspjeh superovulacije u „dan 0" protokolu je manji broj folikula druge i treće kategorije (promjera 3,5 - 5,5 mm) na početku superovulacijskog protokola koji su u pozitivnoj korelaciji s brojem transferabilnih zametaka $(\mathrm{r}=0,67$; $\mathrm{P}<0,05)$. Za uspjeh superovulacijskog protokola u burskih koza osim učinka dominacije od iznimnog su utjecaja brojnost folikula određene veličine na početku superovulacijskog protokola. Primjena FSH hormona pri izvođenju „dan 0” protokola treba započeti u vrijeme kada na jajnicima postoji odgovarajući broj folikula druge kategorije.

Ključne riječi: koza, superovulacija, dominantni folikul, folikularna populacija, zametak, superovulacijski uspjeh 